\title{
Mengenal Tafsir Nusantara: Melacak Mata Rantai Tafsir Dari Indonesia, Malaysia, Thailand, Singapura Hingga Brunei Darussalam
}

\author{
Hasani Ahmad Said \\ UIN Syarif Hidayatullah Jakarta \\ hasaniahmadsaid@uinjkt.ac.id
}

\begin{abstract}
Tafsir (exegesis) scholars traced in the Nusantara archipelago, will not be separated from the figure of 'Abdurrauf al-Fansuri with his Tarjuman alMustafid. Through this work, tafsir had been developed through many media teaching until today. This work also allegedly gave birth to a variety of tafsir model and methodology of qur'anic interpretation in the archipelago. At least two aspects of the interpretation gives birth to the scholars transmission; and to development of the science of interpretation. Firstly, through the activities of teaching; and secondly, through writings. Through these two transmission lines the network of interpretation, until today continues to progress well.
\end{abstract}

\section{Key words: Transmission, Quranic Schoolars, Exegesis, Nusantara}

Abstrak: Melacak jaringan ulama tafsir Nusantara, tidak bisa dilepaskan dari sosok 'Abd al-Raûf al-Fansûrî dengan karyanya Tarjuman al-Mustafid, melalui karya ini terus mengalami perkembangan melalui banyak media pengajaran hingga hari ini. Karya ini pula diduga kuat melahirkan aneka ragam corak dan manhaj tafsir di Nusantara. Paling tidak ada dua aspek transmisi ulama tafsir melahirkan dan mengembangkan ilmu tafsir. Pertama, melalui aktifitas pengajian, dan yang kedua melalui jalur penulisan. Melalui kedua jalur ini transmisi ulama tafsir hingga saat terus mengalami perkembangannya baik.

\section{Kata Kunci: jaringan, ulama, tafsir, nusantara}

\section{Pendahuluan}

Diskursus penting perihal keagamaan yang sedang ramai diperbincangkan di Indoensia saat ini adalah istilah Islam Nusantara. Meskipun bukan istilah baru, istilah Islam Nusantara kembali mencuat pasca digelarnya acara pembukaan Istighosah jelang Ramadhan dalam rangka pembukaan Munas ormas Islam terbesar di Indoensia, Nahdlatul Ulama, di Masjid Istiqlal hari Minggu 14 Juni 2015 yang lalu. Sebagaimana yang dikatakan Said Aqil Siraj, 
ketua Umum PBNU, NU akan mengawal dan memperjuangkan model Islam Nusantara. ${ }^{1}$ Bahkan tema Munas NU yang diusung adalah "Meneguhkan Islam Nusantara untuk Peradaban Indonesia dan Dunia". ${ }^{2}$ Bahkan, sebelumnya ramai pula diperbicangkan lantunan ayat suci Alquran dengan langgam jawa dilantunkan di Istana negara pada PHBI dalam rangka peringatan Isra Mikraj.

Semangat NU mengusung Islam Nusantara didakwahkan untuk merangkul budaya, melestarikan budaya. Merangkul budaya, tidak malah memberangus budaya. Setali tiga uang, gagasan ini disambut baik oleh Presiden RI, Joko Widodo dalam sambutan pembukaan munas tersebut dengan mengatakan: "Islam kita adalah Islam Nusantara, Islam yang penuh sopan santun, Islam yang penuh tata krama, itulah Islam Nusantara, Islam yang penuh toleransi". ${ }^{3}$

Gagasan ini banyak menuai pro dan kontra. Hizbut Tahrir Indonesia juga mempertanyakan sikap yang memperhadapkan konsep Islam Nusantara dengan Islam di Timur Tengah yang dianggap tidak tepat, kata Ismail Yusanto, Jubir HTI. Begitupun Sekjen PAS (Pembela Ahlu Sunnah) Jabar, Syarif Hidayat mengemukakan bahwa ide Islam Nusantara Merupakan Gagasan untuk Mengerdilkan Islam. ${ }^{4}$ Hasyim Muzadi (Anggota Dewan Pertimbangan Presiden) lebih senang mengutarakan, "Islam rahmatan li AL-âlalamîn (rahmat bagi seluruh alam) dibanding Islam Nusantara, karena itu dianggap lebih otentik karena tercantum dalam Alquran sehingga tidak salah lagi. Kalau Islam Nusantara, nanti di Singapura saja sudah tidak diterima. Menggunakan nama lokal atau nasional saja, nanti yang lain tidak tercakup. Nanti ada Islam Amerika, Islam Manila dan lainnya. Kalau Islam rahmatan li al'alamin paling jitu. $^{5}$

Bachtiar Nasir, Sekjen Majelis Intelektual dan Ulama Muda Indonesia (MIUMI) menegaskan, gagasan Islam Nusantara yang diusung oleh kelompok liberal dan didukung oleh Menteri Agama, identik dan cenderung pada sinkretisme. Ada upaya mencampuradukkan Islam dengan budaya. Gagasan ini error dan salah niat. ${ }^{6}$

Berbeda dengan pendapat sebelumnya, Azyumardi Azra, Cendekiawan Muslim Indoensesia mengatakan: "Sektarian di Indonesia itu jauh, jauh lebih kurang dibandingkan dengan sektarianisme yang mengakibatkan kekerasan terusmenerus di negara-negara Arab". T Tokoh-tokoh lain yang setuju dengan pandangan 'Islam Nusantara' sebagaimana Ketua PBNU dan Azzumardi Azra, Wapres Jusuf Kalla, dan Sejarawan NU Agus Sunyoto (Penulis Atlas Walisongo). ${ }^{8}$ Selain itu Muhammadiyah, organisasi Islam terbesar kedua di Indonesia merespon isu Islam Nusantara dalam musyawarah nasionalnya di 
Makasar dengan sitilah "Islam Berkemajuan" sepertinya tidak jauh berbeda dengan istilah "Islam Hadari" yang pernah dicanangkan oleh mantan Perdana Menteri Malaysia Ahmad Badawi ketika berkuawsa di Malaysia.

Seolah membenarkan gagasan Geertz yang menyatakan bahwa Islam Indonesia sangat kaya dengan polarisasinya. Sejak prakemerdekaan, Islam sudah menunjukkan wajah beraneka ragam dan memunculkan banyak nama seperti: Islam abangan, Islam puritan, Islam skriptualis, Islam substantif, Islam literal, Islam ekstrim, Islam militan, Islam tradisionalis, Islam modernis, dan sebagainya. ${ }^{9}$

Terlepas dari pro kontra di atas, di antara bagian dari khazanah Islam Nusantara adalah jaringan ulama yang mengakar di Nusantara baik itu di Indonesia, Malaysia, Brunei Darussalam, Singapura, Thailand dan di Selatan Pilipina. Jaringan ulama dalam tulisan ini lebih menitik beratkan pada ulama tafsir Nusantara. Meskipun tidak menafikan juga jaringan ulama dalam bidang keilmuan lain seperti tasawuf, fikih, dan dalam rumpun kajian Islam lainnya.

Melacak jaringan ulama tafsir Nusantara, tidak bisa dilepaskan dari sosok 'Abd al-Raûf al-Fansûrî dengan karyanya Tarjuman al-Mustafid, melalui karya ini terus mengalami perkembangan melalui banyak media pengajaran hingga hari ini. Karya ini pula diduga kuat melahirkan aneka ragam corak dan manhaj tafsir di Nusantara. Paling tidak ada dua aspek transmisi ulama tafsir melahirkan dan mengembangkan ilmu tafsir. Pertama, melalui aktifitas pengajian, dan yang kedua melalui jalur penulisan. ${ }^{10}$ Melalui kedua jalur ini transmisi ulama tafsir hingga saat terus mengalami perkembangannya baik.

Kajian Al-Qur'an di Nusantara terus mengalami geliat perkembangan yang membanggakan. Munculnya karya-karya tafsir di belahan bumi nusantara menegasikan bahwa kajian Al-Qur'an di bumi nusantara terus mengalami perkembangan. Bukan hanya itu, tafsir Al-Qur'an yang sering disajikan dengan budaya aslinya yaitu kultur Arab, disajikan dengan budaya para pembacanya, dalam hal ini bumi Nusantara. Pada bab ini akan dijelaskan konsepsi penafsiran secara umum meliputi konsepsi penafsiran Al-Qur'an, model penafsiran, dan sejarah penafsiran Al-Qur'an. Tidak kalah pentingnya dengan konsepsi penafiran Al-Qur'an, pada bab ini juga dipaparkan konsepsi tafsir nusantara yang meliputi bahasan tentang pengertian nusantara, mata rantai tafsir Nusantara, serta gaya dan tipologi tafsir di Nusantara. Pada bab ini juga akan disoroti model dan tradisi penafsiran Al-Qur'an di Nusantara, mulai dari Indonesia, Malaysia, Thailand, Singapura dan Brunei Darussalam. 


\section{Konsepsi Penafsiran al-Qur'an}

\section{Pengertian Penafiran}

Membahas penafsiran dari sisi derivasinya, secara etimologis, kata tafsìr (exegesis) berasal dari bahasa Arab, fassara-yufassirutafsiran. Derivasi ini mengandung dua pengertian yaitu menyingkap (al-Kashfu), memperjelas (ižhār) atau menjelaskan. ${ }^{11}$ Sejalan dengan pendapat al-Jurjani, Warson memberikan pengertian kata tafsīr yang merupakan bentuk mașdār berarti menjelaskan, memberi komentar, menterjemahkan atau mentakwilkan. ${ }^{12}$ Pada sisi ini, Warson menyamakan tafsir dengan takwil. Selain dua pendapat yang telah di ulas, Ibnu Manẓūr dalam kamus besar Lisān al-'Arāb memberikan keterangan yang lebih lengkap, ia berkata: kata al-fasru berarti menyingkap sesuatu yang tertutup, sedangkan al-tafsiir menyingkap sesuatu lafaz yang susah dan pelik. ${ }^{13}$

Dari tiga pendapat yang dipaparkan di atas, menurut hemat penulis tafsir dalam perspektif bahasa selain mengandung arti menjelaskan dan menyingkap, juga mempunyai arti lain yakni mengungkap sesuatu yang sulit yang sulit untuk dihadirkan pada makna yang mudah dipahami. Dengan demikian, secara etimologi, tafsir berarti menjelaskan (اليضاح), menerangkan (التبين), menampakan ( الظهار ), menyibak (الكشف) dan merinci (التفصيل). Tafsir berasal dari isim masdar dari wajan (نفعيل). Kata tafsir diambil dari bahasa arab yaitu yang artinya menjelaskan. Pengertian inilah yang dimaksud di dalam Lisan al'Arab dengan ( membuka sesuatu yang tertutup ). Pengertian tafsir secara bahasa ditulis oleh Ibnu Mahdzur ialah membuka dan menjelaskan maksud yang sukar dari suatu lafaz. Pengertian ini pulalah yang diistilahkan oleh para ulama tafsir dengan (menjelaskan dan menerangkan). Sedangkan di dalam kamus bahasa indonesia kata tafsir diartikan dengan keterangan atau penjelasan tentang ayat-ayat Al-Qur'an.

Di atas telah diungkap tafsir dalam perspektif bahasa, maka pada sisi ini akan dijelaskan tafsir dalam pengertian istilah. Secara terminologis, tafsīr adalah ilmu yang membahas tentang apa yang dimaksud oleh Allah dalam Al-Qur'an sepanjang kemampuan manusia. ${ }^{14}$ Kata tafsir dalam Al-Qur'an disebut satu kali yaitu dalam Q.S. al-Furqān/25: 33, sedang kata yang sering disepadankan dan disejajarkan dengan tafsīr ialah ta'wīl disebut dalam Al-Qur'an sebanyak 17 kali. ${ }^{15} \mathrm{Di}$ antara para ahli ada yang menyamakan pengertian antara keduanya, namun ada juga yang membedakannya, kontroversi ini disampaikan antara lain oleh al-Zarqāni. ${ }^{16}$

Ibn 'Abbas, yang dinilai sebagai salah seorang sahabat Nabi yang paling mengetahui maksud firman-firman Allah, menyatakan bahwa tafsir terdiri dari empat bagian: pertama, yang dapat dimengerti secara umum oleh orang-orang 
Arab berdasarkan pengetahuan bahasa mereka; kedua, yang tidak ada alasan bagi seseorang untuk tidak mengetahuinya; ketiga,yang tidak diketahui kecuali oleh ulama; dan keempat, yang tidak diketahui kecuali oleh Allah. ${ }^{17}$

Syaikh Thahir al-Jazairy, dalam at-Taujih menyatakan bahwa tafsir pada hakekatnya ialah menerangkan (maksud) lafazh yang sukar dipahami oleh pendengar dengan uraian yang lebih memperjelas pada maksud baginya, baik dengan mengemukakan sinonimnya atau kata yang mendekati sinonim itu, atau dengan mengemukakan (uraian) yang mempunyai petunjuk kepadanya melalui suatu jalan dalalah."

Menurut Syaikh Al-Jurjani dalam At-Ta'riifat menyatakan bahwa paada asalnya, tafsir berarti membuka dan melahirkan. Dalam pengertian syara', (tafsir) ialah menjelaskan makna ayat: dari segi segala persoalannya, kisahnya, asbabun nuzulnya, dengan menggunakan lafazh yang menunjukkan kepadanya secara terang."

Al-Zarkasyi menjelaskan Tafsir ialah ilmu (pembahasan) yang mengkaji tentang pemahaman kitabullah yang diturunkan kepada Nabi Muhammad saw, menerangkan makna-maknanya, megeluarkan hukum-bukum yang dikandungnya serta ilmu-ilmu (bikmah) yang ada di dalamnya."

Selain pendapat di atas, 'Abd al-Azhim al-Zarqani dalam Manahil al-'Irfan fi 'Ulum al-Qur'an mengatakan:

$$
\text { علم يبحث عن القران الكريم من حيث دللته على مر اد الله تعالى بقدر الطاقة البشرية }
$$

"Ilmu yang membahas tentang al-Qur'an dari segi dilalahnya berdasarkan maksud yang dikehendaki oleh Allah sebatas kemampuan manusia"

Dari definisi di atas dapat diambil kesimpulan, bahwa tafsir adalah usaha yang bertujuan menjelaskan Al-Qur'an atau ayat-ayatnya atau lafazhlafazhnya, agar yang tidak jelas menjadi jelas, yang samar-samar menjadi terang, yang sulit dipahami menjadi mudah dipahami, sehingga Al-Qur'an sebagai pedoman hidup manusia benar-benar dapat dipahami, dihayati dan diamalkan, demi tercapainya kebahagiaan hidup dunia dan akhirat.

\section{Model Penafsiran}

Sebelum mengupas tentang metode penafsiran Al-Qur'an, pada bagian ini akan di bahas manhaj (pendekatan) dalam penafsiran AlQur'an. Dilihat dari sumber pengambilan atau orientasi penafsirannya, tafsir dapat dibedakan ke dalam tiga aliran besar yakni tafsîr bi alriwâyah, tafsîr al-dirâyah, dan tafsîr bi al- 
isyârah. Ketiga pendekatan tafsir ini timbul dan berkembang seiring dengan kebutuhan umat dan tuntunan zaman.

Pada mulanya lahir tafsîr al-riwâyah, kemudian diikuti dengan tafsîr aldirâyah dan akhirnya tafsîr bi al-isyârah. Kelahiran tafsîr aldirâyah selain karena kebutuhan mendesak pada zamannya, juga sebagai kritik terhadap aliran tafsîr al- al-riwâyah yang dianggap terlalu sedidkit. Demikian pula dengan tafsîr bi alisyârah, lahir sebagai reaksi atas aliran tafsir bi al-dirâyah yang dianggap terlalu mendewakan akal dengan mengabaikan peranan intuisi.

Tafsîr al-riwâyah atau dalam sebutan lain bi al-ma'tsur, atau al-manqul ialah tafsir yang terdapat dalam al-Qur'an, atau sunnah atau pendapat sahabat, dalam rangka menerangkan apa yang dikehendaki Allah Swt. Tentang penafsiran al-Qur'an berdasarkan al-Sunnah Nabawiyyah. Dengan demikian tafsir bi al-ma'tsur adakalanya menafsirkan alQur'an dengan al-Qur'an, atau menafsirkan al-Qur'an dengan sunnah Nabawiyah, atau menafsirkan al-Qur'an dengan yang dikutip dari pendapat sahabat. ${ }^{18}$

Menurut Ibnu Taimiyah, sebaik-baik cara menafsirkan Al-Qur'an ialah hendaknya menafsirkan Al-Qur'an dengan Al-Qur'an, sebab perkara yang dijelaskan dengan mujmal pada suatu tempat maka ia telah diperincikan di tempat lain atau dirangkaikan pada suatu tempat telah pula diterangkan secara keseluruhan di tempat lain. ${ }^{19}$ Jika tidak terdaoat dalam Al-Qur'an, hendaknya mencarinya dari sunnah, karena Sunnah juga merupakan tafsiran dan uraian terhadap Al-Qur'an. ${ }^{20}$

Sedangkan tafsir bi al-dirayah atau dalam istilah lain bi al-ma'qul, bi alra'yi, dan bi al-ijtihad ialah penafsiran yang dilakukan berdasarkan ijtihad mufassir setelah mengenali lebih dahulu bahasa Arab dari segi argumentasinya yang dibangun dengan menggunakan syai'r-sya'ir jahili serta mempertimbangkan sabab al-nuzûl dan lain-lain yang dibutuhkan oleh mufassir. $^{21}$

Secara selintas tafsir dengan menggunakan pendekatan al-dirâyah lebih berorientasi kepada penalaran yang bersifat aqli (rasional) dengan menggunakan pendekatan kebahasaan yang menjadi dasar penjelasannya. Itulah sebabnya mengapa para ulama berbeda-beda pendapat dalam menilai tafsir bi alra'yi. Begitu juga halnya dengan ijtihad dan tafsir bi al-ra'yi yang memungkinkan hasilnya akan benar atau salah.

Setelah membahas thariqah (pendekatan) tafsir, pada bagian ini akan dibahas metode tafsir Al-Qur'an. Seiring dengan berjalannya waktu, ilmu tafsir terus berkembang dan jumlah kitab tafsir terus bertambah dalam beraneka corak. Para ulama tafsir belakangan memilih kitab-kitab itu berdasarkan metode 
penulisannya ke dalam empat bentuk tafsir, yaitu metode tahlili, ijmâli, muqarin, dan maudû' ${ }^{22}$ Sebagaimana disebutkan di atas, al-Farmawi, membagi metode (tarîqah) tafsir yang selama ini dipakai ulama menjadi empat, yakni: tahlili, ijmali, muqaran, dan maudu'i. Kemudian dari empat metode tersebut, metode tahlili diperinci kembali menjadi tujuh corak, yakni: al-tafsir as-Sufi, fiqhi, falsafi, 'ilmi dan tafsir al-adab al-Ijtima'i. ${ }^{23}$

Di bawah ini akan diberikan penjelasan masing-masing mengenai metode (tarîqah) tafsir.

1. Tahlîlî (Deskriptif-Analisis)

Secara harfiyah, al-tahlîlî berarti menjadi lepas atau terurai. Yang dimaksud dengan tafsir tahlili adalah metode penafsiran ayat-ayat al-Qur'an yang dilakukan dengan cara mendiskriptifkan uraianuraian makna yang terkandung dalam ayat-ayat al-Qur'an itu sendiri dengan sedikit banyak melakukan analisis di dalamnya. ${ }^{24}$ Tafsir Tahlili biasa juga tafsir analitis, menafsirkan al-Qur'an secara tahlili berarti menafsirkan al-Qur'an sesuai urutan mushaf dengan memaparkan berbagai aspek yang terkandung di dalamnya seperti makna lafaz, sabab al-nuzul, munasabat, riwayat-riwayat yang terkait dan lain-lain. ${ }^{25}$

2. Ijmâli (Global)

Secara bahasa, kata ijmâli berarti ringkasan, ikhtisar, global dan penjumlahan. Dengan demikian maka yang dimaksud dengan metode ijmali adalah suatu metode penafsiran al-Quran yang dilakukan dengan cara mengemukakan makna umum (global). ${ }^{26}$ Dengan metode ini mufasir menjelaskan makna ayat-ayat alQur'an secara garis besar.

Sistematikanya mengikuti urutan surah-surah al-Qur'an, sehingga makna-maknanya dapat saling berhubungan dalam menyajikan maknamakna ini, mufasir menggunakan ungkapanungkapan yang diambil dari alQur'an sendiri dengan menambahkan kata-kata atau kalimat-kalimat penghubung, sehingga memberi kemudahan kepada para pembaca untuk lebih mudah memahaminya.

Dalam menafsirkan ayat-ayat al-Qur'an dengan metode ini, mufasir juga meneliti, mengkaji, dan menyajikan asbâb al-nuzûl atau peristiwa yang melatarbelakangi turunnya ayat, dengan cara meneliti hadis-hadis yang berhubungan dengannya.

3. Muqaran (Perbandingan)

Sesuai dengan namanya, metode muqaran adalah metode tafsir yang dilakukan dengan cara memba nding-bandingkan ayat-ayat al-Qur'an yang 
memiliki redaksi berbeda padahal isi kandungannya sama, atau antara ayatayat yang memiliki redaksi yang mirip padahal isi kandungannya berbeda.

4. Maudî́i (Tematik)

Secara bahasa metode maudû'i adalah berarti metode tafsir tematis. Metode ini dibagi menjadi dua: Pertama, adalah tafsir yang membahas satu surah al-Qur'an secara menyeluruh, memperkenalkan dan menjelaskan maksudmaksud umum dan khususnya secara garis besar, dengan cara menghubungkan ayat yang satu dengan ayat yang lainnya, dan atau antara satu pokok masalah dengan pokok masalah lainnya. ${ }^{27}$ Kedua adalah, tafsir yang menghimpun dan menyusun ayat-ayat al-Qur'an yang memiliki kesamaan arah dan tema, kemudian memberikan penjelasan dan mengambil kesimpulan, di bawah bahasan satu tema tertentu. ${ }^{28}$

Metode tahlili sebuah metode yang mendominasi tafsir-tafsir klasik baik yang dengan penekatan bi al-ma'tsur seperti al-Durr al-Mansur fi al-Tafsîr bi al-Ma'tsur karya Jalaluddin al-Suyuti (849-911 H), Jami' al-Bayân 'an Ta'wil ayat al-Qur'an, karya Abu Ja'far Muhammad Ibnu Jarir al-Tabari $(224$ H-310 H), dan Tafsîr al-Qur'an al-Azîm karya Imaduddîn Abu alFida' al-Quraisy alDimasyqy Ibnu Katsir (700-774 H), ataupun yang bercorak bi alma'qul seperti Tafsir Jalalain karya Jalal al-din al-Mahalli dan Jalal al-din al-Suyuti.

\section{Sejarah Penafsiran Alqur'an}

Awal mula penafsiran Al-Qur'an sudah terjadi pada diri Rasulullah Saw. Maka banyak ahli mengungkapkan bahwa mufassir pertama adalah Rasulullah Saw. Hal ini dibuktikan dengan data bahwa setiap kali Rasulullah Saw, menerima wahyu, maka ketika Rasulullah menerima wahyu dari Allah melalui perantara malaikat Jibril, seketika itu pula Rasulullah Saw, menyampaikan kepada para Sahabat. ${ }^{29}$

Walaupun bangsa Arab pada waktu itu masih buta huruf, tapi mereka mempunyai ingatan yang sangat kuat. Pegangan mereka dalam memelihara dan meriwayatkan syair-syair dari para pujangga, peristiwa-peristiwa yang terjadi dan lain sebagainya adalah dengan hafalan semata. Karena hal inilah Nabi mengambil suatu cara praktis yang selaras dengan keadaan itu dalam menyiarkan dan memelihara AlQur'an. Setiap ayat yang diturunkan, Nabi menyuruh menghafalnya, dan menuliskannya di batu, kulit binatang, pelapah kurma, dan apa saja yang bisa dituliskan. Nabi menerangkan tertib urut ayatayat itu. Nabi mengadakan peraturan, yaitu Al-Qur'an saja yang boleh dituliskan, selain dari Al-Qur'an, Hadits atau pelajaran-pelajaran yang mereka 
dengar dari mulut Nabi dilarang untuk dituliskan. Larangan ini dengan maksud agar Al-Qur'an itu terpelihara, jangan dicampur aduk dengan yang lain-lain yang juga didengar dari Nabi.

M. Quraish Shihab menuliskan, pada saat al-Quran diturunkan, Rasul Saw., yang berfungsi sebagai mubayyin (pemberi penjelasan), menjelaskan kepada sahabat-sahabatnya tentang arti dan kandungan al-Quran, khususnya menyangkut ayat-ayat yang tidak dipahami atau samar artinya. Keadaan ini berlangsung sampai dengan wafatnya Rasul SAWW, walaupun harus diakui bahwa penjelasan tersebut tidak semua kita ketahui akibat tidak sampainya riwayat-riwayat tentangnya atau karena memang Rasul Saw. sendiri tidak menjelaskan semua kandungan Al-Quran. ${ }^{30}$

Setelah Rasulullah wafat (11 H.), kepeloporan beliau di bidang tafsir dilanjutkan oleh para sahabat. Di antara sahabat-sahabat yang ahli di bidang tafsir misalnya: Khulafä' al-Rāshidīn Abu Bakar (w. 13 H.), 'Umar bin alKhat\}t \{āb (w. 23 H.), 'Uthmān bin 'Affān (w. 35 H.), dan 'Ali bin Abī T\}ālib (w. 40 H.), Ibn 'Abbās (w. 68 H.), 'Abd Allah dan Zubayr, Ubay bin Ka'b (w. 20 H.), Zayd bin Thābit, dan Abū Mūsā al-Anșārī (w. 44 H.). lihat, Jalāl al-Dīn al-Suyūt\}īi, al-Itqān fī 'Ulūm al-Qur'ān (Bayrūt: Dār al-Fikr: tt.), 27-28. Di samping sepuluh sahabat yang tergolong sebagai ahli tafsir dan pelanjut penafsiran yang dilakukan oleh Nabi, yaitu Abū Hurayrah (w.58 H.), Anas bin Mālik, 'Abd Allah bin 'Umar (w. 73 H.), Jābir bin 'Abd Allah, A'īshah (w. 57 H.), dan 'Amr bin 'Aș. Mereka dipandang sebagai generasi pertama mufassir. ${ }^{31}$

Sejarah perkembangan tafsir tidak terlepas dari corak penafsiran yang dihasilkan oleh setiap generasi dalam penggal sejarah tertentu, di mana dalam menyajikan kandungan dan pesan-pesan firman Allah Swt. terdapat ekspresi dan karakter yang impresif. Jangankan pada generasi yang berbeda, generasi yang samapun, seperti generasi sahabat sudah emperlihatkan fenomena perselisihan pendapat dalam memahami AlQur'an.

Dalam kenyataan sejarahnya, pemahaman dan penafsiran terhadap AlQur'an memiliki kecenderungan dan corak yang berbeda-beda dari satu generasi ke generasi berikutnya, antara satu kelompok dengan kelompok yang lainnya. Perbedaan corak penafsiran ini tidak bisa dilepaskan dari perbedaan madhhab, setting sosial, kemampuan intelektual dan juga niat atau tujuan mufassir dalam menulis kitab tafsirnya tersebut. Satu hal yang perlu diingat bahwa Al-Qur'an tidak akan pernah habis di tafsirkan. Di sisi lain, keragaman penafsiran yang dihasilkan tiap generasi juga merupakan gambaran konsekuensi logis dari keyakinan bahwa Al-Qur'an, sebagai kitab suci yang diturunkan terahkir, mampu berdialog dengan setiap generasi yang datang kemudian. 
Ajaran dan semangat yang dibawanya bersifat universal, rasional, dan necessary (suatu keniscayaan dan keharusan yang fitri). ${ }^{32}$

Gabungan dari tiga sumber di atas, yaitu penafsiran Rasul Saw., penafsiran sahabat-sahabat, serta penafsiran tabi'in, dikelompokkan menjadi satu kelompok yang dinamai Tafsir bi al-Ma'tsûr. Dan masa ini dapat dijadikan periode pertama dari perkembangan tafsir. Berlakunya periode pertama tersebut dengan berakhirnya masa tabi'in, sekitar tahun $150 \mathrm{H}$, merupakan periode kedua dari sejarah perkembangan tafsir. Pada periode kedua ini, hadis-hadis telah beredar sedemikian pesatnya, dan bermunculanlah hadis-hadis palsu dan lemah di tengahtengah masyarakat. Sementara itu perubahan sosial semakin menonjol, dan timbullah beberapa persoalan yang belum pernah terjadi atau dipersoalkan pada masa Nabi Muhammad SAWW, para sahabat, dan tabi'in.

\section{Konsep Tafsir di Nusantara}

\section{Pengertian Nusantara}

Istilah nusantara dalam Kamus Besar Bahasa Indonesia diartikan sebuah (nama) bagi seluruh wilayah kepulauan Indonesia. ${ }^{33}$ Dalam berbagai disiplin ilmu, nusantara juga sering dipakai menjadi sebuah tema kajian. Misalnya, Azyumardi Azra, dalam karyanta Jaringan Global dan Lokal Islam Nusantara penerbit Bandung: Mizan, tahun 2002; buku disertasinya diberi judul Jaringan Ulama Timur Tengah dan Kepulauan Nusantara Abad XVII dan XVIII, Jakarta, penerbit Mizan, 1998. T.E. Behrend, et.al. Katalog Induk NaskahNaskah Nusantara jilid 4, Perpustakaan Nasional Indonesia, Jakarta: YOI, 1998. Wan Moh. Șaghir Abdullah Șaghir, Perkembangan Ilmu Tasawuf dan TokoTokohnya di Nusantara, Surabaya: al-Ikhlas, 1980, Ervan Nurtawab. "Melacak Tradisi Awal Penafsiran Al-Qur'an di Nusantara." Jurnal Lektur Keagamaan 4:2, (2006). Izza Rahman Nahrawi. "Profil Kajian Al-Qur'an di Nusantara Sebelum Abad ke 20.” Jurnal al-Huda, II, no.6, (2000). ${ }^{34}$

Islam Nusantara menurut Azyumardi Azra adalah Nusantara: Islam is a distinctive Islam resulting from vivid, intense and vibrant interaction, contextualization, indigenization and vernacularization of universal Islam with Indonesian social, cultural and religious realities — this is Islam embedded. Nusantara Islamic orthodoxy (Ash'arite theology, Shafi'i school of law, and Ghazalian Sufism) nurtures the Wasatiyyah character-a justly balanced and tolerant Islam. Nusantara Islam, no doubt, is very rich with Islamic legacy-a shining hope for a renaissance of global Islamic civilization". "Islam Nusantara adalah Islam distingtif sebagai hasil interaksi, kontekstualisasi, indigenisasi dan vernakularisasi Islam universal dengan realitas sosial, budaya dan 
agama di Indonesia. Ortodoksi Islam Nusantara (kalam Asy'ari, fikih mazhab Syafi'i, dan tasawuf Ghazali) menumbuhkan karakter wasathiyah yang moderat dan toleran. Islam Nusantara yang kaya dengan warisan Islam (Islamic legacy) menjadi harapan renaisans peradaban Islam global". ${ }^{35}$

Menurut Indra Fakhruddin, istilah Islam Nusantara tidak bisa dipisahkan dari imbas global stigma negatif terhadap Islam dan kaum muslimin. Dalam hal ini barat, berhasil membuat skenario untuk menciptakan opini bahwa islam khususnya di Timur Tengah berwajah seram. Merekalah dalang yang membuat kondisi timur tengah notabene poros peradaban islam carut-marut penuh konflik dan darah sambil menampilkan simbol-simbol islam. Simbol-simbol Islam inilah yang dilemparkan kepublik. Sehingga masyarakat dunia menangkap Islam Timur Tengah tidak ramah, santun dan toleran. Disisi lain menggambarkan Nusantara sarat dengan tradisi yang lebih toleran, moderat dan tidak radikal. ${ }^{36}$

\section{Mata Rantai Tafsir di Nusatara}

Melacak tradisi awal penafsiran Al-Qur'an di nusantara, banyak peneliti seperti Riddell, ${ }^{37}$ A.H. Johns, ${ }^{38}$ Salman Harun, ${ }^{39}$ Azyumardi Azra, ${ }^{40}$ Ervan Nurtawab $^{41}$ dan lain-lain menginformasikan bahwa sekitar abad ke-XVII M. telah ditemukan bukti paling awal di Nusantara setelah lebih dari 300 tahun sejak komunitas Muslim Nusantara itu mulai mewujudkan dirinya dalam kekuasaan politik, yaitu di Cambridge yang memuat tafsir surat al-Kahfi. Kajian Al-Qur'an dipelopori oleh 'Abd al-Ra'ūf al-Sinkīlī yang menulis kitab dengan berjudul Tarjumān al-Mustafìd. Dua karya inilah yang menjadi embrio pijakan penulisan tafsir Al-Qur'an di Asia tenggara. ${ }^{42}$ Upaya rintisan ini kemudian diikuti oleh Shaykh Nawāwī al-Bantanīi, ${ }^{43}$ Munawar Khalil, ${ }^{44}$ A. Hasan Bandung, ${ }^{45}$ Mahmud Yunus, ${ }^{46}$ Oemar Bakri, ${ }^{47}$ Hasbi Ash-Shiddiqy, ${ }^{48}$ Hamka, ${ }^{49}$ H. Zainuddin Hamidy dan Fachruddin Hs, ${ }^{50}$ Kasim Bakri. ${ }^{51}$ Dalam bahasabahasa daerah, upaya ini dilanjutkan oleh Kemajuan Islam Yogyakarta, ${ }^{52}$ Bisyri Muṣtahafa Rembang, ${ }^{53}$ R. Muhammad Adnan, ${ }^{54}$ dan Bakri Syahid..$^{55}$ Upayaupaya ini bahkan lebih diseriusi oleh Pemerintah RI melalui proyek penerjemahan. Selanjtnya, atas usul Musyawarah kerja Ulama Al-Qur'an ke XV (23-24 Maret 1989), disempurnakan oleh pusat penelitian dan pengembangan Lektur Agama bersama Lajnah Pentashih Al-Qur'an. ${ }^{56}$ Howard M. Federspiel dalam penelitiannya, kurang lebih disebut 48 tafsir popular di Indonesia, ${ }^{57}$ walaupun masih perlu dikritisi batasan apa saja yang ia anggap sebagai karya tafsir. 


\section{Gaya dan Tipologi Tafsir di Nusatara}

Tafsir nusantara yang dimaksud di sini adalah dalam bidang tafsir. Gaya dan tipologi tafsir nusantara banyak terwarnai dengan Islam local baik itu budaya maupun kondisi saat ayat-ayat Al-Qur'an dilakukan tafsiran oleh sang penafsirnya. Tipologi dan gaya penafsiran ala nusantara tentu sedikit berbeda dengan tafsiran yang sudah dikenal selama ini. Misalnya, tafsir klasik memiliki ciri khas tersendiri di banding dengan tafsir bernuansa modern. Begitupun tafsir nusantara akan sedikit berbeda warnanya dengan model penafsiran yang dihasilkan oleh penafir dari Timur Tengah. Hal inilah yang menarik dari tafsir khas ala nusantara.

Selain itu, gaya dan tipologi tafsir nusantara tidak lepas dari transmisi tradisi tafsir Hijaz, Azhari, dan sarjana Barat. Hijaz di sini adalah transmisi cara penulisan, pemikiran dan tradisi tafsir yang berkembang di Makkah maupun Madinah. Kemudian, tafsir nusantara juga memiliki ketersambungan dan keterikatan kuat dengan pola pikir al-Azhar Mesir yang banyak melahirkan ulama-ulama nusantara yang secara tidak langsung ikut menyumbangkan pemikiranannya dalam menelurkan karya tafsir nusantara. Kedua sisi ini lebih kental mencuat pada abad XVI hingga awal abad XX. Selain kedua sisi ini, adapula sisi lain yang tidak kalah pentingnya yaitu gagasan dan pemikiran baik dari sarjana muslim Indonesia yang belajar di Barat maupun sarjana Barat sendiri yang ikut meramaikan penelitian dan analisis tentang tafsir nusantara. Dari kesemua sisi itu, yang tidak akalah pentingnya adalah sisi lokalitas (local wisdom) ulama local baik terkait tentang social dan budaya nusantara maupun sarjana didikan asli nusantara yang tentu memiliki corak tersendiri di banding dengan transmisi keilmuan yang belajar dari Hijazi, Azhari maupu Barat.

\section{Tradisi Penafsiran Alqur'an di Alam Nusantara \\ 1. Penafsiran Alqur'an di Indoneisa}

Indonesia menjadi bagian penting dari munculnya penafsiran di bumi Nusantara. Bagaimana tidak, lahirnya Tarjuman al-Mustafid karya 'Abdurrauf Singkel menjadi awal mula penafsiran Al-Qur'an di Nusantara.

Membincang tafsir di Indonesia, kita akan menemukan karyakarya yang menjadi rujukan awal yang khusus dan focus melakukan kajian yang mendalam terhadap tafsir Indonesia. Howard M. Federshiel seorang peneliti tafsir Indoensia memaparkan paling tidak ada 48 tafsir yang ditelaahnya. Di antara 48 mufassir yang Federspiel sebut adalah, Munawar Khalil, Aboe Bakar Atjeh, Bahrum Rangkuti, Jamaluddin Kafie, Oemar Bakrie, Joesoef Sou'eb, M. Hasbi alShiddiqy, Masjfuk Zuhdi, A. Hasan, Qomaruddin Hamidy, Mahmud Yunus, 
Hamka, Abdul Halim Hasan, Tafsir Depag, Bachtiar Surin, Sukmadjadja Asyarie, Badarutthanan Akasah, Syahminan Zaini, MS. Khalil, Qamaruddin Saleh Nasikun, Bey Arifin, Labib MZ, A. Hanafi, Hadiyah Salim, M. Ali Usman, Khadijatus Shalihah, A. Muhaimin Zen, Datuk Tombak Alam, A. Djohansjah, Ismail Tekan, T. Atmadi Usman, Abu Hanifah, Zainal Abidin Ahmad, HB. Jassin, Mahfudi Sahli, Dja'far Amir, Muslih Maruzi, Abdul Aziz Masyhuri, M. Munir Farunama, Syahminan Zaini, M. Ali Husayn, A. Syafi'I Ma'arif, Dawan Raharjo, Azwar Anar, Imam Munawwir, Z. Kasijan, Nazwar Syamsu, M. Quraish Shihab. ${ }^{58}$

Dari 48 tafsir yang dipaparkan di atas, Federspiel mengambil sampel penelitian secara serampangan dalam artian dia mengungkapkan karya-karya yang dia anggap tafsir kendati tidak semua dianggap sebagai mufassir di kalangan masyarakat umum. Meskipun demikian, karya ini banyak dijadikan rujukan oleh banyak peneliti.

Selain karya Howard Federspiel di atas, akan ditemukan pula karya Salman Harun yang mengungkap tafsir Indonesia. Dia mengulas Tafsir Tarjuman alMustafid dalam sebuah karya disertasinya. Karya ini penting dan banyak memberikan kontribusi yang berarti bagi para peneliti. Sebagai penulis generasi awal asli Indoensia, karyanya menjadi penting yang mengulas informasi perkembangan tafsir Indonesia. ${ }^{59}$

Karya yang hampir sama dengan Howar Federspiel, ada pula karya Islah Gusmian yang menjadi karya akademik S2nya. Dia mengulas peta tafsir di Indonesia. ${ }^{60}$ Dan masih banyak karya yang sama yang mengulas tafsir Indonesia. Bahkan, peta kajian perkembangan tafsir di Indonesia masuk dalam kurikulum di perguruan tinggi khususnya pada jurusan Tafsir Hadis di PTAIN / PTAIS Kementerian Agama RI.

\section{Penafsiran Alqur'an di Malaysia}

Melacak jaringan ulama tafsir di Malaysia, kita akan temukan karya Mustaffa Abdullah yang berjudul Khazanah Tafsir di Malaysia, terbitan Akademi Pengajian Islam Uniersiti Malaya, Malaysia. Di dalam bukunya ini, ia mengungkapkan model pengajaran tafsir di Malaysia, mulai dari pondok, institusi pendidikan formal dan tidak formal. Setelah memaprkan model pengajian dan pengajaran tafsir di Malaysia, ia mengungkapkan tokoh-tokoh tafsir di Malaysia. Ada 26 mufassir di Malaysia yang diungkapkan oleh Mustaffa mulai dari Syekh Abdul Malik Abdullah (1650-an - 1736) sampai Abdullah arRahmat. ${ }^{61}$ 
Penelitian yang dilakukan Mustaffa menunjukkan betapa banyak hamparan tafsir Malaysia. Kendati Mustaffa menyebutkan bahwa perkembangan tafsir di Malaysia, tidak semaju Indonesia. Namun demikian, penelitian ini sangat membantu bagi pengkaji awal.

\section{Penafsiran Alqur'an di Thailand}

Negara yang dikenal dengan julukan negeri gajah putih ini, jika ditelusuri secara sejarah bahwa Islam masuk ke Thailand dengan melalui Kerajaan Pasai (Aceh). Ketika Kerajaan Pasai ditaklukan Thailand, raja Zainal Abidin dan orang-orang Islam banyak yang ditawan. Setelah mereka membayar tebusan mereka dikeluarkan dari tawanan, dan para tawanan tersebut ada yang pulang dan ada juga yang menetapa di Thailand, sehingga mereka menyebarkan agama Islam. Chapakia menuturkan bahwa kedatangan Islam di Patani (selatan Thailand) berkisar sekitar abad ke-7 M. ${ }^{62}$

Embrio ini muncul ketika raja Thailand menekan Sultan Muzaffar Syah (1424-1444) dari Malak agar tetap tuduk kepada Thailand dengan membayar upeti sebanyak 40 tahil emas per tahun ditolaknya, kemudian Raja Pra Chan Wadi menyerang Malaka, tetapi penyerangan tersebut gagal. Pada masa pemerintahan Sultan Mansyur Syah (1444-1477) tentara Thailand di Pahang dapat dibersihkan. Wakil Raja Thailand yang bernama Dewa Sure dapat ditahan, tetapi beliau diperlakukan dengan baik. Bahkan, puterinya diambil istri oleh Mansyur Syah untuk menghilangkan permusuhan antara Thailand dengan Malaka. Kendati belakangan in, muslim Pattani cukup lama mendapat tekanan dan penindasan dari rezim Bangkok yang memeluk Budha. Salah satu provinsi yang ada di Thailand adalah Pattani. Pattani atau dikenal dengan Thai merupakan salah satu provinsi (changwat) di selatan Thailand. Provinsiprovinsi yang bertetangga (dari arah selatan tenggara searah jarum jam) adalah Narathiwat (Menara), Yala (Jala) dan Songkhla (Senggora). Masyarakat Melayu setempat menyebut provinsi mereka, Patani Darussalam atau Patani Raya.

Nama Pattani menarik untuk penulis kemukakan di sini, paling tidak ada dua alas an. Pertama, Pattani merupakan salah satu daripada empat provinsi Thailand yang mempunyai mayoritas penduduk beragama Islam (80\%). Nama Pattani berasal dari dua perkataan Bahasa Melayu logat setempat yaitu "Pata" ("Pantai") dan "Ni" ("Ini"). Sebagai salah satu wilayah baru yang terbentuk dari Negara Patani awal, demografinya tidak jauh berbeda dengan provinsi-provinsi mayoritas Melayu Islam yang lain seperti Narathiwat(Menara), Yala (Jala), Satun (Sentul) dan Songkhla (Senggora). Kedua, AlFattani adalah dari 
perkataan Bahasa Arab bermaksud kebijaksanaan atau cerdik, karena di situ tempat lahirnya banyak ulama dan cendikiawan berbagai golongan dari tanah melayu (jawi). Banyak juga yang menjadi ahli tafsir $\mathrm{Al}$-quraan, pengarang kitab bahasa Arab dan bahasa Melayu serta banyak juga yang telah menjadi tenaga pengajar di tanah Arab kebanyakan dari Fattani maka orang-orang Arab menggelar mereka adalah orang Fattani. Maka dari itu, Fattani juga dikenal sebagai serambi Mekah atau yang lebih po[uler dengan Fattani Darulsalam.

Perkembangan kajian Islam di Thailand tidak terlepas dari peranan pata tokoh-tokoh ulama Thailand, khususnya di daerah Patani. Adapun ulamaulama Patani itu adalah misalnya Syeikh Daud, Syeikh Ahmad, Syeikh Muhammad bin Ismail dan lain-lain. Mereka inilah yang banyak menghasilkan penulisan-penulisan ilmiah dan secara tidak langsung mereka turut memengaruhi keberagamaan masyarakat Patani. Hanya saja karya-karya para ulama pendahulu Patani, tulisan dan pemikirannya masih tertumpu pada bidang tauhid, fiqh dan tasawuf, ilmu alat dan sebagainya. Sangat disayangkan karya-karya mereka tidak atau tidak banyak mengupas bidang tafsir al-Qur'an. ${ }^{63}$ Namun demikian, kendati tidak menunjukkan kemeriahan dan pengaruh yang amat besar terhadap perkembangan dunia pengajaran dan penulisan tafsir di Thailand, akan tetapi menurut Dr. Mohd. Lazim Lawee para muballigh tidak hanya menyebarkan Islam juga dimungkinkan juga mengajarkan $\mathrm{Al}-\mathrm{Qur}$ 'an yang sesuai dengan tahap keislaman dan penerimaan penduduk masa itu. ${ }^{64}$ Namun demikian, Lazim Lawee melanjutkan penuturannya bahwa dalam bidang tafsir Al-Qur'an hanya menuliskan di dalam kitab-kitab tauhid, fikih, tasawuf, dalam menguraikan bahasan-bahsan yang dibicarakn dalam bidang tersbut. ${ }^{65}$

Jika di sisir, di Patani (selatan Thailand), pengajian tafsir al-Qur'an tidak begitu jelas, kalau adapun yang diajar di institusi pengajian pondok atau sekolah hanya dengan menggunakan buku-buku tafsir dalam bahasa Arab sebagai teks, seperti kitab "Tafsir al-Jalayn" dan syarah-syarahnya, "Tafsir al-Maraghi" karangan Ustaz Ahmad Mustafa al-Maraghi, "Tafsir al-Wadih” karangan Dr. Muhammad Mahmud Hijazi, dan sebagainya. Untuk sekolah rendah menggunakan tafsir juz 'amma, karangan Abi Luqman, cetakan Kelantan Darul Naim pada tahuntahun 70an.

Pada awal abad ke-15H, muncul nama Prof. Dr. Ismail Luthfi yang saat ini menjadi rektor di Jamiah Fathoni (University Fathoni) dan seorang Mufti kerajaan Thailand yang memberikan pembaharuan corak pengajian tafsir di Patani dengan mengadakan pengajian umum yang dikenali sebagai Maljis al- 
Ilmi, bertempat di Masjid Ibadurrahman, Madrasah al- Rahmaniah, Beraul, Patani pada setiap hari Sabtu. ${ }^{66}$

Penafsiran Al-Qur'an di Thailand bermula dari pengajian biasa yang biasa diadakan di masjid, majlis taklim secara rutin. Dari pengajian-pengajia tafsir itulah pengasuhnya menulis catatan dan tulisan ringkas dan selanjutnya di edit secara apik dan rapih. Maka dari itulah lahir Tafsir al-Bayan. Tafsir al-Bayan adalah satu di antara sekian banyak hamparan karya tafsir yang dihasilkan oleh ulama Thailand. Mushtaffa bin Abdullah dan Abdul Manan Syafi'I, dalam penelitiannya yang dimuat di Jurnal Kontekstualitas yang berjudul "Khazanah Tafsir di Nusantara: Penelitian terhadap Tokoh dan Karyanya di Malaysia, Brunei Darussalam, Singapura dan Thailand" menyebutkan 37 karya tafsir Thailand. ${ }^{67}$ Dalam penelitian Rorsuedee Salaeh Rushdi dan.Ishak Suliaman, Dr.Ismail Lutfi: Peranannya dalam Penulisan Tafsir Qur'an di Selatan Thailand, menyebutkan untuk karya Ismail Luthfi saja hingga saat ini ada 31 karya dibidang tafsir.

\section{Penafsiran Alqur'an di Brunai}

Agama Islam di Brunei memiliki posisi khusus tersendiri bagai masyarakatnya. Hal ini cukup beralasan karena agama Islam di Brunei merupakan agama resmi negara. Untuk pengembangan agama Islam lebih lanjut telah didatangkan ulama-ulama dari luar negeri, termasuk dari Indonesia. Masjid-masjid banyak didirikan. Umat Islam di Brunei menikmati kehidupan yang benar-benar sejahtrera sesuai dengan namanya Darussalam (negeri yang damai). Pendapatan perkapita negara ini termasuk tertinggi di dunia. Pendidikan dan perawatan kesehatan diberikan secara cuma-cuma oleh pemerintah. Negara Brunei Darussalam merupakan negara termuda di Asia Tenggara (merdeka tahun 1984 dari Inggris). Penduduk Brunei Darussalam mayoritas beragama Islam.

Masuknya Islam di Brunei tidak lepas dari penyebaran masuknya Islam di Nusantara. Indikasi kuat terlihat dari bangunan-bangunan masjid yang megah pada masanya hingga saat ini. Adapun pengajian tafsir di Brunei terlihat dari silabus yang diajarkan pada sekolah dan madrasah bahkan perguruan tinggi yang ada di Brunei Darussalam mulai tahun $1968 .{ }^{68}$ Sekolah-sekolah agama yang dimaksud adalah Maktabah Sultan Omar Ali Saifuddin (Bandar Brunei), Sekolah Melayu Muhammad Jamalul Alam (Bandar Brunei), Sekolah Melayau Ahmad Tajuddin (Pekan Belait), Sekolah Melayu Muda Hashim (Pekan Tutong), Sekolah Melayu Muhammad Alam (Pekan Seria) Sekolah Melayu 
Laila Mencanai (Bandar Brunei), dan Sekolah Melayu Sultan Hasan, Pekan Bangar (Temburong) ${ }^{69}$

Kemudian yang tidak kalah pentingnya adalah peranan University Brunei Darussalam (UBD) yang menuodorkan pengajian tafsir AlQur'an di bawah jabatan Tafsir Hadis, Fakultas Ushuluddin, Institut Pengajian Islam, UBD. Di antara objek kajian tafsirnya adalah Tafsir al-'Adzim karya Ibn Kathir, al-Jami' li Ahkam al-Qur'an karya alQurthubi, al-Kasyaf 'an Haqaiq al-Tanzil wa 'Uyun al-Aqawil fi Wujuh al-Ta'wil karya al-Zamakhsyari, al-Muhayyar al-Wajiz fi Tafsir al-Kitab al-'Aziz karya Ib 'Athiyyah, Tafsir al-Munir karya Wahbah Zuhayli dll. ${ }^{70}$

Menurut Dr. Abdurrahman Haqqi seorang dosen di INISA, Syarif 'Ali dan juga penulis Tafsir Janzabil agak susah untuk mencari tafsir Brunei Darussalam. ${ }^{71}$ Bias dikatakan juga perkembangan tafsir karya ulama Brunei Darussalam jauh tertinggal disbanding dengan Negara bumi nussantara lainnya. Hal ini bias dimengerti karena alas an jumlah penduduknya yang sedikit yaitu sebanyak 249 ribu jiwa saja pada tahun 1990-an.

Namun, pada tahun 2000-an Brunei yang terdiri dari dua bagian yang tidak berkaitan; 97\% dari jumlah penduduknya tinggal di bagian barat yang lebih besar, dengan hanya kira-kira 10.000 orang tinggal di daerah Temburong, yaitu bagian timur yang bergunung-gunung. Jumlah penduduk Brunei 470.000 orang. Dari bilangan ini, lebih kurang 80.000 orang tinggal di ibukota Bandar Seri Begawan. Sejumlah kota utama termasuk kota pelabuhan Muara, serta kota Seriayang menghasilkan minyak, dan Kuala Belait, kota tetangganya. Di daerah Belait, kawasan Panaga ialah kampung halaman sejumlah besar ekspatriat, disebabkan oleh fasilitas perumahan dan rekreasi Royal Dutch Shell dan British Army. Klub Panaga yang terkenal terletak di sini. Iklim Brunei ialah tropis khatulistiwa, dengan suhu serta kelembapan yang tinggi, dan sinar matahari serta hujan lebat sepanjang tahun.

Menurut Mufti Kerajaan Brunei Darussalam, Pehin Dato' Seri Maharajo Dato Paduka Seri Setia Haji Awang Abdul Aziz bin Juned, selain factor keterlambatan penduduk, bisa juga karena kurangnya pakar tafsir yang ada di Brunei Darussalam. ${ }^{72}$

Namun demikian, berbagai upaya terus dilakukan oleh pemerintah maupun oleh lembaga dan perorangan. Paling tidak peneliti punya data empat karya tafsir yang ada di Brunei Darussalam. Meskipun sebagaiannya lebih tepat dikatakan terjemah. Mushtaffa bin Abdullah dan Abdul Manan Syafi'I, Khazanah Tafsir di Nusantara menyebut 3 karya tafsir, sebagai berikut: 
1. Tafsir Darussalam, (dalam bentuk majalah berseri dari 1972 hingga 1995) buah karya dari Pegawai-pegawai Jabatan Hal Ehwal Agama dan Guru Sekolah Menengah Arab Hasanah Bolkiah / Sekolah Menengah Arab Anak Damit, penerbit Jabatan Hal Ehwal Agama Brunei (1972-1986) Pusar Da'wah Islamiyah (1987-1995);

2. Tafsir Lengkap 30 Juz (belum diterbitkan) karya Jawatan kuasa menyusun dan menyeleksi yang disepakati oleh Musyawarah Penerbitan Tafsir Darussalam Lengkap 30 Juz, penerbit Pusar Da'wah Islamiyah dengan kerja sama Dewan Bahasa san Pustaka dan Jabatan Percetakan Kerajaan;

3. Tafsir al-Muntakhob (belum diterbitkan), karya Dr. Haji Muhammad Nur Lubis;

Sedangkan satu tafsir lagi peneliti menemukan dari seorang pensyarah di University Islam Sultan Syarif 'Ali yang bernama DR. Haji Abdurrahman bin Raden Aji Haqqi bersama DR. H. Muhammad Nabil Almunawwar, M.Sc. menulis Tafsir Janzabil. Abdurrahman Haqqi adalah asli keturunan Bogor yang sudah lama mengabdi di Brunei Darussalam sebagai pengajar senior di Fakultas Syariah dan Undang-undang, Universiti Islam Sultan Syarif Ali (UNISSA), Brunei Darussalam sejak 2007. Sebelumnya ia juga bekerja dengan pekerjaan yang sama di Uinversiti Brunei Darussalam (UBD) dari tahun 2000 hingga 2007. ${ }^{73}$ Sedangkan Dr. H. Muhammad Nabil Almunawwar adalah dosen di School of Business \& Ecokomics, University Brunei Darussalam. Nabil juga merupakan adik kandung dari Prof. Dr. said Agil Husin al-Munawwar, M.A.74

\section{Penafsiran Alqur'an di Singapura}

Islam sebagai agama yang minoritas di Singapura, kurang lebih hanya 16\% penduduk mengamalkan ajaran Islam. Kebanyakan warga Singapura yang beragama Islam ini terdiri dari golongan orang Melayu. Orang Melayu tidak lagi berkelompok di sesuatu lokasi. Sebaliknya mereka diselerakkan di seluruh Singapura.

Kendati Islam menjadi penduduk yang minoritas, tidak lantas semangat umat Islam kendor. Adanya Majelis Ugama Islam Singapura (MUIS) menjadi bagian penting dalam pengembangan agama Islam di Singapura. Seiring dengan berjalannya waktu, Islam di Singapura terus mengalami perkembangan baik dalam dunia pendidikan maupun pengajian dan kajian Islam. Perhatian para ulama Singapura akan keberlangsungan Islam di Singapura menjadi sesuatu yang penting bagi keberlangsungan Islam di Singapura. Ketika membincang perkembangan khazanah tafsir di Singapura, rasanya sulit dilepaskan 
dari sosok Ahmad Sonhaji. Karena jerih payahnya menyapaikan pesanpesan Al-Qur'an dalam berbagai tempat dan media, khususnya dalam bidang tafsir.

Dalam bidang perkembangan penafsiran Al-Qur'an, paling ada 5 karya tafsir yang menonjol. Empat karya itu adalah:

1. Tafsir al-Qur'an (edisi Singapura) karya Ahmad Sonhaji Muhammad, penerbit Pustaka Qalam, Singapura tahun 1960;

2. Tafsir al-Qur'an 'Abr al-Athir / Tafsir al-QUr'an di Radio (edisi Malaysia) karya Ahmad Sonhaji Muhammad 30 juz lengkap, penerbit Pustaka alMizan / Syarikat Prema, Malaysia, tahun 1989;

3. Pedoman Kemuliaan Pada Mentafsirkan al-Qur'an (Tafsir Surah al-Fatihah dan al-Baqarah) karya Fadhlullah Suhaimi yang diterbitkan oleh Muhammadiyah Press, Muar Johor cetakan pertama tahun 1924 dan cetakan kedua pada tahun 1956;

4. Pelita al-Qur'an (Surah al-Baqarah (Surah al-Baqarah / Ali 'Imran / al-Nisa' I Juz 'Amma karya Abdullah al-Jufri penerbit Pustaka Nasional Singapura pada tahun 2001;

5. Pedoman Tafsir Juz Amma karya Osman Jantan penerbit Pustaka Nasional Singapura tahun 2006.

\section{Kesimpulan}

Kajian ini menginformasikan bahwa betapa luasnya lautan ilmu yang ada pada ulama-ulama tafsir di Nusantara. Penelitian ini juga memberikan jalan baru untuk para pengkaji dan bisa jadi untuk pengambil kebijakan dalam hal ini bisa jadi pemerintah. Bahwa jaringan Nusantara tidak hanya pada keilmuan saja, akan tetapi bisa digali dari sisi yang lain demi merekatkan sekaligus mengingatkan kembali bahwa kita adalah sama-sama berada di bumi Nusantara dengan berbagai macam persamaannya.

Ketika menyelamai lautan samudera tafsir dan tokoh tafsir nusantara maka banyak perspektif muncul misalnya ada ulama tafsir nusantara yang secara khusus menampilkan tafsir nusantara dengan bahasa Jawi Melayu-nya, di sisi yang lain ada pula dengan bahasa lokal misalnya al-Nawawi al-Jawi yang menulis bahasa tafsirnya dengan bahasa Arab. Pada sisi yang lain ada pula penulisan tafsirnya dengan bahawa Jawi Melayu namun dengan perkembangan dan berjalannya

waktu tafsir tersebut dialih bahasakan dalam bahasa negaranya. Selain yang telah disebutkan tadi di atas, karena perkembangan dan kemajuan zaman pada 
abad 20 dan 21 ini banyak tafsir yang sudah tidak lagi menggunakan aksara Jawi Melayu, akan tetapi langsung dari bahasa asal negaranya.

\section{Daftar Pustaka}

Abdullah Mustaffa, Khazanah Tafsir di Malaysia, Malaysia: Akademi Pengajian Islam University Malaya, 2009

Abdullah, Musthaffa bin dan Abdul Mannan Syafi'i, "Khazanah Tafsir di

Nusantara: Penelitian Terhadap Tokoh dan Karyanya di Malaysia, Brunei

Darussalam, Singapura dan Thailand",Kontekstualita, Vol. 25, No. 1, Juli 2009

Azra, Azyumardi. "The Transmission of Islamic Reformism to Indonesian:

Networks of Middle Eastern and Malay-Indonesian Ulama in the 17th and

18th Centuries." disertasi doktornya di Departemen Sejarah, Columbia University, 1992

al-Afriqi, Ibnu Manẓūr, Lisān al-'Arāb, Bayrūt: Dār al-Ṣadīr, tth.

Abdullah, Mustaffa, Khazanah Tafsir di Malaysia, (Malaysia: Book Pro Bublishing Service - Akademi Pengajian Islam Universiti Malaysia, 2009

Abdullah, Mushtaffa bin dan Abdul Manan Syafi'i, "Khazanah Tafsir di

Nusantara: Penelitian terhadap Tokoh dan Karyanya di Malaysia, Brunei

Darussalam, Singapura dan Thailand”, Jurnal Kontekstualita, Vol. 25 No.

1, Juli 2009

Adnan, R. Muhammad, Al-Qur'an Suci Basa Jawi, 1969

Bakri, Oemar, Tafsir Rahmat, Jakarta: Mutiara, 1983

Bisyri Mushtahafa Rembang, al-Ibrīz, 1960

Chalil, Munawar, Tafsìr al-Qur'ān Hidayatur Rahman, Jakarta: Siti Sjamsiah, 1958

Chapakia, Ahmad Omar, Politik Thai dan Masyarakat Islam di Selatan Thailand, Kedh Darul Aman: Pustaka Darusslama, 2000

Federspiel, Howard M., Kajian al-Quran di Indonesia Dari Mahmud Yunus Hingga Quraish Shihab, terj., Tajul Arifin, Bandung: Mizan, 1996

al-Bāqi, MuHammad Fu'ad 'Abd, al-Mu-jam al-Mufharas lì al-FāzalQur'ān, Bayrūt: Dār al-Fikr, 1987

Baidan, Nashruddin, Metodologi Penafsiran al-Qur'an, Yogyakarta: Pustaka Pelajar, 2000 
al-Bantani, Shaykh Nawawi, menulis tafsir bertajuk MarāH Labìd lì Kashfi Ma'na Qur'ān al-Majīd, atau dikenal juga dengan Tafsīr al- Munīr. Dicetak di Kairo, al-Halabi, 1887

Burhanuddin, Mamat S., Hermeneutika Al-Quran ala Pesantren (Analisis Trehadap Tafsir Marah Labid Karya KH. Nawawi Banten) (Yogyakarta: UII Press, 2006

al-Dhahabī, MuHamad Husayn, al-Tafsīr wa al-Mufassirūn, Mesir: Maktabah Wahbah, 1985

Depdikbud, Kamus Besar Bahasa Indonesia, Jakarta: Balai Pustaka, 1996

Fazlur Rahman, Islam and Modernity, Chicago: Universitas of Chicago Press, 1982

al-Farmawi, Abd Al-Hayy, al-Bidâyah fì al-Tafsîr al-Maudûi, Dirâsah Manhajiyyah Mauduiyyah, 1977

Geertz, Clifford, The Religion of Java,, Glencoe: Free Press, 1960

Gusmian, Islah, Khazanah Tafsir Indonesia: dari Hermeneutic hingga Idiologi, Jakarta: Teraju, 2003

Harun, Salman, Mutiara Surat al-Fätihah; Analisis Shaykh MuHammad Nawawi Banten (Jakarta: CV Kafur, 2000

Hafiduddin, Didin, Tinjauan atas Tafsir Munir Karya Imam MuHammad Nawawi Tanara dalam Warisan Intelektual Islam Indonesia (Bandung: Mizan, 1987

Hasan, Ahmad, Al-Furqān: Tafsir al-Qur'an, Bangil: Persatuan, $1406 \mathrm{H}$.

Harun, Salman. "Hakekat Tafsir Tarjuman al-Mustafid Karya Shaykh Abdurrauf." disertasi doktornya di IAIN Syarif Hidayatullah Jakarta, 1988.

Hamka, Tafsir al-Azhar, Jakarta: Pustaka Panjimas, 1982

Hamidy, Zainuddin dan Fachruddin Hs, Tafsir al-Qur'an, Jakarta: Wijaya: 1959

Harun, Salman. "Hakekat Tafsir Tarjuman al-Mustafid Karya Shaykh Abdurrauf.” Disertasi doktor, IAIN Syarif Hidayatullah Jakarta, 1988.

Haqqi, Abdurrahman R.A. dan Muhammad Nabil Almunawaar, Tafsir Zanjabil: Surah Ali Imran, Tematik, Modern, Ringkas, (Jakarta: Qisthi Press, 2015

al-Jurjani, 'Ali bin MuHammad bin 'Ali, al-Ta'rifāt, Bayrūt: Dār al- Kutub al'Arabi, $1405 \mathrm{H}$. 
Johns, Anthony H., Islam di Dunia Melayu: Sebuah Survei Penyelidikan dengan Beberapa Referensi Kepada Tafsir Alquran, dalam Azyumardi Azra, Perspektif Islam Asia Tenggara, Jakarta: YOI, 1987

Lawee, Mohd. Lazim, "Pengajaran Pengajian Alquran dan Hadis di Thailand", makalah seminar warisan Alquran dan Hadis di Nusantara di Universitas Malaya, 2008

Lawee, Mohd. Lazim, Khazanah al-Qur'an dan Hadith Nusantara, Kuala Lumpur: Akademi Pengajian Islam, 2009

M. Quraish Shihab dalam pengantar buku Taufik Adnan Amal. Rekonstruksi Sejarah Al-Qur'an, Jakarta: Pustaka al-Fabets, 2005

Munawwir, A.Warson, Kamus al-Munawwir, Yogyakarta: Unit Pengadaan Buku PP al-Munawwir, 1984

Nurtawab, Ervan. "Discourse on Translation in Hermeneutics: Its Application to The Analysis of Abdurra'uf 's Turjuman al-Mustafis." tesis di Sekolah Pascasarjana UIN Syarif Hidayatullah, Jakarta, tahun 2007

Riddell, Peter G.. "Abdurra'uf al-Sinkili’s Tarjunān al-Mustafīd: A Critical Study of His Treatment of Juz 16." disertatasi Dotornya di Australia National University tahun 1984

Riddell, "From Kitab Malay to Literary Indonesian: A Case Study in Semantic Change." Indo-Islamika, Journal of Islamic Science, Sekolah Pascasarjana UIN Syarif Hidayatullah Jakarta, 5, November 1, 2008

al-Suyūt\}īi, Jalāl al-Dīn, al-Itqān fì 'Ulūm al-Qur'ān, Bayrūt: Dār al- Fikr: tt.

al-Sabûnî, Muhammad 'Ali, al-Tibyân fî 'Ulûm al-Qur'ân, Damsyik: Maktabah al-Ghazali, 1981

Shihab, M. Quraish, Rasionalitas al-Quran Studi Kritis atas Tafsir al-Manar, Jakarta: Lentera Hati, 2006 , Membumikan al-Quran, Bandung: Mizan, 1997

, Wawasan al-Qur'an Tafsir Tematik atas Pelbagai Persoalan Umat, Bandung: Mizan, 2007

Yusoff, Zulkifli Hj Mohd dan Muhammad Mukhlis Hj Mohd Yunus, Kajian al-Qur'an, Kuala Lumpur Malaysia: Centre of Qurnaic Research (CQR), 2015

al-Qat\}t\}ān, Mannā' Khalīl, MabāHith fì 'Ulūm al-Qur'ān, Bayrūt: Manshūrāt al-'Așr al-Hadìth, $1393 \mathrm{H}$. 
Said, Hasani Ahmad, Diskursus Munasabah al-Qur'an dalam Tafsir al-Mishbah, Jakarta: Amzah, 2015

Rushdi, Rorsuedee Salaeh dan.Ishak Suliaman, "Dr. Ismail Lutfi: Peranannya dalam Penulisan Tafsir Qur'an di Selatan Thailand" makalah yang diakses dari Dr.Ismail_Lutfi_Peranannya_dalam_Penulisan_Tafsir_Qur_a.pdf.

Taimiyah, Imam Ibn, Pengantara Kepada Usul al-Tafsir, terj. Zulkifli Haji Mohd Yusoff dan Abdurrahim Yapono, Selangor: MAP Intel Multimedia And Publication

Ash-Shiddiqy, Hasbi, Tafsir An-Nur, Jakarta: Bulan Bintang, 1976

Yunus, Mahmud, Tafsìr Qur'ān Karim, Jakarta: Pustaka Mahmudiyah, 1957

al-Zarqānī, Manāhil al-'Irfān fì 'Ulūm al-Qur'ān, Bayrūt: Dār al-Fikr, tth.

al-Zarqānī, Manāhil al-Irfān fì 'Ulūm al-Qur'ān, Bayrūt: Dār al-Fikr, tt.

Al-Zarkasyi, Al-Burhan fi 'Ulum Al-Qur'an, Mesir: Al-Halabiy, 1957

\section{Internet}

http://www.bbc.com/indonesia/berita_indonesia/2015/06/150614_ indonesia_islam_nusantara.

www.nu.or.id.

http://voa-islam.com/read/indonesiana/sekjen-pas-jabar-ide-islam-nusantaramerupakan-gagasan-untuk-mengerdilkan/\#dpuf

www.antaranews.com, 21 Mei 2015

https://iervie.wordpress.com/2015/06/16/ustadz-bachtiar-nasir-gagasan-islamnusantara-identik-dengan-sinkretisme/.

https://www.islampos.com/menyoal-gagasan-islam-nusantara-189397/.

\section{Endnotes}

1. Lihat Heyder Affan, "Polemik di Balik Istilah 'Islam Nusantara", diakses dari http://www.bbc.com/indonesia/berita_indonesia/2015/06/150614_indonesia_ islam_nusantara.

2. Lihat www.nu.or.id.

3. Lihat Heyder Affan, "Polemik di Balik Istilah 'Islam Nusantara", diakses dari http://www.bbc.com/indonesia/berita_indonesia/2015/06/150614_indonesia_ islam_nusantara.

4. Lihat Syahid, "Sekjen PAS Jabar: Ide Islam Nusantara Merupakan Gagasan untuk Mengerdilkan Islam - See more at: http://voa-islam.com/read/ indonesiana/sekjen-pasjabar-ide-islam-nusantara-merupakan-gagasan-untuk-mengerdilkan/\#dpuf, diakses dari: 
http://voa-islam.com/read/ indonesiana//sekjen-pas-jabar-ide-islam-nusantara-merupakangagasan-untuk-mengerdilkan/\#.

5. www.antaranews.com, 21 Mei 2015

6. Sudirman Darwis "Ustadz Bachtiar Nasir: Gagasan Islam Nusantara Identik Dengan Sinkretisme”, https://diervie.wordpress.com/2015/06/16/ ustadz-bachtiar-nasir-gagasanislam-nusantara-identik-dengan-sinkretisme/.

7. Lihat Heyder Affan, "Polemik di Balik Istilah 'Islam Nusantara", diakses dari http://www.bbc.com/indonesia/berita_indonesia/2015/06/150614_indonesiaislam_nusan tara.

8. Mahmud Budi, "Menyoal dari Gagasan Islam Nusantara", diakses dari https:// www.islampos.com/menyoal-gagasan-islam-nusantara-189397/.

9. Clifford Geertz, The Religion of Java, (Glencoe: Free Press, 1960), h. 27.

10. Musthaffa bin 'Abd Allah dan Abdul Mannan Syafi'i, "Khazanah Tafsir di Nusantara: Penelitian Terhadap Tokoh dan Karyanya di Malaysia, Brunei Darussalam, Singapura dan Thailand",Kontekstualita, Vol. 25, No. 1, Juli 2009, h. 31.

11. Lihat 'Ali bin MuHammad bin 'Ali al-Jurjani, al-Ta'rifät (Bayrūt: Dār al-Kutub al-'Arabi, 1405 H.), 87.

12. Lihat A.Warson Munawwir, Kamus al-Munawwir (Yogyakarta: Unit Pengadaan Buku PP al-Munawwir, 1984), 1134.

13. Lihat Ibnu Manzūur al-Afriqi, Lisān al-'Arāb (Bayrūt: Dār al-Ṣadīr, tth.), 55.

14. Lihat al-Zarqānī, Manāhil al-'Irfān fì 'Ulūm al-Qur'ān (Bayrūt: Dār al-Fikr, tth.), h. 3, bandingkan pula dengan MuHamad Husayn al-Dhahabī, al-Tafsīr wa al-Mufassirūn (Mesir: Maktabah Wahbah, 1985), 15.

15. Lihat MuHammad Fu'ad 'Abd al-Bāqī, al-Mu-jam al-Mufharas lì al-Fāz al- Qur'ān (Bayrūt: Dār al-Fikr, 1987), 97.

16. al-Zarqānī, Manāhil al-Irfān fì 'Ulūm al-Qur'ān (Bayrūt: Dār al-Fikr, tt.), 4-6, lihat pula Jalāl al-Dīn al-Suyūt\}彳̄ì, al-Itquàn fì 'Ulūm al-Qur'ān (Bayrūt: Dār al- Fikr: tt.), 173-174.

17. Al-Zarkasyi, Al-Burhan fi 'Ulum Al-Qur'an, (Mesir: Al-Halabiy, 1957), Jilid II. hlm. 164.

18. Muhammad 'Ali al-Sabûnî, al-Tibyân fî̀ 'Ulûm al-Qur'ân, (Damsyik: Maktabah alGhazali, 1981), h. 63

19. Imam Ibn Taimiyah, Pengantara Kepada Usul al-Tafsir, terj. Zulkifli Haji Mohd Yusoff dan Abdurrahim Yapono, (Selangor: MAP Intel Multimedia And Publication), h. 71.

20. Imam Ibn Taimiyah, Pengantara Kepada Usul al-Tafsir, h. 71.

21. Muhammad Husein al-Dzahabî, al-Tafsîr wa al-Mufassirûn, (Kairo: Maktabah Wahbah, 2000), juz 1, h. 295

22. Abd Al-Hayy al-Farmawi, al-Bidâyah fî al-Tafsîr al-Maudû'I, (Dirâsah Manhajiyyah Mauduiyyah, 1977), h. 23.

23. Abd Al-Hayy al-Farmawi, al-Bidâyah fî al-Tafsîr al-Maudûl, h. 25; bandingkan dengan M. Quraish Shihab, Rasionalitas al-Quran Studi Kritis atas Tafsir al-Manar (Jakarta: Lentera Hati, 2006), 24-25, bandingkan pula, M. Quraish Shihab, Membumikan alQuran (Bandung: Mizan, 1997), 83-91, M. Quraish Shihab, Wawasan al-Qur'an Tafsir Tematik atas Pelbagai Persoalan Umat (Bandung: Mizan, 2007), xv-xvi..

24. Abd Al-Hayy al-Farmawi, al-Bidâyah fî al-Tafsîr al-Maudû̀I, h. 7. 
25. Lihat Nashruddin Baidan, Metodologi Penafsiran al-Qur'an, (Yogyakarta: Pustaka Pelajar, 2000), h. 2.

26. Abd Al-Hayy al-Farmawi, al-Bidâyah fî al-Tafsîr al-Maudû I, h. 25.

27. Abd Al-Hayy al-Farmawi, al-Bidâyah fî al-Tafsîr al-Maudû́I, h. 50.

28. Azyumardi Azra (ed.), Sejarah dan Ulum al-Qur'an, h. 193.

29. Zulkifli Hj Mohd Yusoff dan Muhammad Mukhlis Hj Mohd Yunus, Kajian al- Qur'an, (Kuala Lumpur Malaysia: Centre of Qurnaic Research (CQR), 2015), h. 10.

30. M. Quraish Shihab, Membumikan Alquran

31. Lihat lebih lanjut, Mannā' Khalīl al-Qat\}t\}ān, MabāHith fì 'Ulūm al-Qur'ān (Bayrūt: Manshūrāt al-'Aṣr al-Hadīth, 1393 H.), 343.

32. Adalah suatu kenyataan sejarah, bahwa pemahaman dan penafsiran terhadap Alquran memiliki kecenderungan dan corak yang berbeda-beda dari satu generasi ke generasi berikutnya, antara satu kelompok dengan kelompok yang lainnya. 126. Perbedaan corak penafsiran ini tidak bisa dilepaskan dari perbedaan madhhab, setting sosial, kemampuan intelektual dan juga niat atau tujuan mufassir dalam menulis kitab tafsirnya tersebut. Satu hal yang perlu diingat bahwa Alquran tidak akan pernah habis di tafsirkan. Di sisi lain, keragaman penafsiran yang dihasilkan tiap generasi juga merupakan gambaran konsekuensi logis dari keyakinan bahwa Alquran, sebagai kitab suci yang diturunkan terahkir, mampu berdialog dengan setiap generasi yang datang kemudian. Ajaran dan semangat yang dibawanya bersifat universal, rasional, dan necessary (suatu keniscayaan dan keharusan yang fitri). Lihat, Fazlur Rahman, Islam and Modernity (Chicago: Universitas of Chicago Press, 1982), 11.

33. Lihat, Depdikbud, Kamus Besar Bahasa Indonesia (Jakarta: Balai Pustaka, 1996), 569.

34. Hasani Ahmad Said, Diskursus Munasabah al-Qur'an dalam Tafsir al-Mishbah, (Jakarta: Amzah, 2015), h. 19.

35. "Islam Nusantara Adalah Kita, diakses dari http://fah.uinjkt.ac.id/index. php/20articles/kolom-fahim/197-islam-nusantara-adalah-kita.

36. Indra Fakhruddin, "Quo Vadis Islam Nusantara", diakses dari http://www. arrahmah.com/rubrik/quo-vadis-islam-nusantara.html\#sthash.1ZJ9ss10.dpuf.

37. Peter G. Riddell. “Abdurra'uf al-Sinkili’s Tarjunān al-Mustafïd: A Critical Study of His Treatment of Juz 16." disertatasi Dotornya di Australia National University tahun 1984, dalam karya yang lainnya, Riddell menulis "From Kitab Malay to Literary Indonesian: A Case Study in Semantic Change." Indo- Islamika, Journal of Islamic Science, Sekolah Pascasarjana UIN Syarif Hidayatullah Jakarta, 5, November 1, (2008/1429).

38. Anthony H. Johns, Islam di Dunia Melayu: Sebuah Survei Penyelidikan dengan Beberapa Referensi Kepada Tafsir Alquran, dalam Azyumardi Azra, Perspektif Islam Asia Tenggara (Jakarta: YOI, 1987).

39. Salman Harun. "Hakekat Tafsir Tarjuman al-Mustafid Karya Shaykh Abdurrauf." disertasi doktornya di IAIN Syarif Hidayatullah Jakarta, 1988.

40. Azyumardi Azra. "The Transmission of Islamic Reformism to Indonesian: Networks of Middle Eastern and Malay-Indonesian Ulama in the 17th and 18th Centuries." disertasi doktornya di Departemen Sejarah, Columbia University tahun 1992. Disertasi ini kemudian di terjemahkan dengan judul Jaringan Ulama Timur Tengah dan Kepulauan 
Nusantara Abad ke-17 dan 18: Melacak Akar-Akar Pembaharuan Pemikiran Islam di Indonesia, dicetak pertama kali oleh Mizan, Bandung tahun 1994.

41. Ervan Nurtawab. "Discourse on Translation in Hermeneutics: Its Application to The Analysis of Abdurra'uf's Turjuman al-Mustafis." tesis di Sekolah Pascasarjana UIN Syarif Hidayatullah, Jakarta, tahun 2007. Tesis Ervan kemudian diterbitkan setelah diolah ulang dengan judul Tafsir al-Quran Nusantara Tempo Doeloe, Jakarta: Ushul Press, 2009. 127

42. Lihat M. Quraish Shihab dalam pengantar buku Taufik Adnan Amal. Rekonstruksi Sejarah Al-Qur'an (Jakarta: Pustaka al-Fabets, 2005), vi.

43. Shaykh Nawawi al-Bantani, menulis tafsir bertajuk MarāH Labìd lì Kashfi Ma'na Qur'ān al-Majīd, atau dikenal juga dengan Tafsīr al-Munīr. Dicetak di Kairo, al-Halabi, 1887. Lihat buku Mamat S. Burhanuddin, Hermeneutika Al- Quran ala Pesantren (Analisis Trehadap Tafsir Marah Labid Karya KH. Nawawi Banten) (Yogyakarta: UII Press, 2006), Salman Harun, Mutiara Surat al-Fätihah; Analisis Shaykh MuHammad Nawawi Banten (Jakarta: CV Kafur, 2000), Didin Hafiduddin, Tinjauan atas Tafsir Munir Karya Imam MuHammad Nawawi Tanara dalam Warisan Intelektual Islam Indonesia (Bandung: Mizan, 1987).

44. Munawar Chalil, Tafsìr al-Qur'ān Hidayatur Rahman, (Jakarta: Siti Sjamsiah, 1958).

45. Ahmad Hasan, Al-Furqān: Tafsir al-Qur'an (Bangil: Persatuan, 1406 H.).

46. Mahmud Yunus, Tafsìr Qur'ān Karim (Jakarta: Pustaka Mahmudiyah, 1957).

47. Oemar Bakri, Tafsir Rahmat (Jakarta: Mutiara, 1983).

48. Hasbi Ash-Shiddiqy, Tafsir An-Nur (Jakarta: Bulan Bintang, 1976).

49. Hamka, Tafsir al-Azhar, (Jakarta: Pustaka Panjimas, 1982).

50. Zainuddin Hamidy dan Fachruddin Hs, Tafsir al-Qur'an (Jakarta: Wijaya: 1959).

51. Kasim Bakri, Tafsir al-Quranul Hakim, 1960.

52. Kemajuan Islam Yogyakarta, Quran Kejawen Sundawiyah.

53. Bisyri Mushtahafa Rembang, al-Ibriz, 1960.

54. R. Muhammad Adnan, Al-Qur'an Suci Basa Jawi, 1969.

55. Bakri Syahid, Al-Huda, 1972

56. M. Quraish Shihab dalam pengantar buku Taufik Adnan Amal. Rekonstruksi Sejarah AlQur'an (Jakarta: Pustaka al-Fabets, 2005), vi. Dalam bentuk karya Tim Penerjemah alQuran Depag RI, Al-Quran dan Terjemahnya (Jakarta: Yayasan Penyelenggara Penerjemah/penafsiran Al-Quran, Depag RI, 1975).

57. Di antara 48 mufassir yang Federspiel sebut adalah, Munawar Khalil, Aboe Bakar Atjeh, Bahrum Rangkuti, Jamaluddin Kafie, Oemar Bakrie, Joesoef Sou'eb, M. Hasbi alShiddiqy, Masjfuk Zuhdi, A. Hasan, Qomaruddin Hamidy, Mahmud Yunus, Hamka, Abdul Halim Hasan, Tafsir Depag, Bachtiar Surin, Sukmadjadja Asyarie, Badarutthanan Akasah, Syahminan Zaini, MS. Khalil, Qamaruddin Saleh Nasikun, Bey Arifin, Labib MZ, A. Hanafi, Hadiyah Salim, M. Ali Usman, Khadijatus Shalihah, A. Muhaimin Zen, Datuk Tombak Alam, A. Djohansjah, Ismail Tekan, T. Atmadi Usman, Abu Hanifah, Zainal Abidin Ahmad, HB. Jassin, Mahfudi Sahli, Dja'far Amir, Muslih Maruzi, Abdul Aziz Masyhuri, M. Munir Farunama, Syahminan Zaini, M. Ali Husayn, A. Syafi'I Ma'arif, Dawan Raharjo, Azwar Anar, Imam Munawwir, Z. Kasijan, Nazwar Syamsu, M. Quraish Shihab. Lihat, Howard M. Federspiel, Kajian al-Quran 128 di Indonesia Dari Mahmud Yunus Hingga Quraish Shihab, terj., Tajul Arifin, (Bandung: Mizan, 1996). 
58. Lihat, Howard M. Federspiel, Kajian al-Quran di Indonesia Dari Mahmud Yunus Hingga Quraish Shihab, terj., Tajul Arifin, (Bandung: Mizan, 1996).

59. Lihat lebih lanjut Salman Harun. "Hakekat Tafsir Tarjuman al-Mustafid Karya Shaykh Abdurrauf.” Disertasi doktor, IAIN Syarif Hidayatullah Jakarta, 1988.

60. Islah Gusmian, Khazanah Tafsir Indonesia: dari Hermeneutic hingga Idiologi, (Jakarta: Teraju, 2003).

61. Lihat, Mustaffa Abdullah, Khazanah Tafsir di Malaysia, (Malaysia: Book Pro Bublishing Service - Akademi Pengajian Islam Universiti Malaysia, 2009), h. 43-319.

62. Ahmad Omar Chapakia, Politik Thai dan Masyarakat Islam di Selatan Thailand (Kedh Darul Aman: Pustaka Darusslama, 2000), h. 18.

63. Rorsuedee Salaeh Rushdi dan.Ishak Suliaman, "Dr. Ismail Lutfi: Peranannya dalam Penulisan Tafsir Qur'an di Selatan Thailand" makalah yang diakses dari Dr.Ismail_Lutfi_Peranannya_dalam_Penulisan_Tafsir_Qur_a.pdf.

64. Lihat Mohd. Lazim Lawee, "Pengajaran Pengajian Alquran dan Hadis di Thailand", makalah seminar warisan Alquran dan Hadis di Nusantara di Universitas Malaya, 2008, h. vxi. Lihat pula Mushtaffa bin Abdullah dan Abdul Manan Syafi'I, "Khazanah Tafsir di Nusantara: Penelitian terhadap Tokoh dan Karyanya di Malaysia, Brunei Darussalam, Singapura dan Thailand", Jurnal Kontekstualita, Vol. 25 No. 1, Juli 2009, h. 41.

65. Mohd. Lazim Lawee, Khazanah al-Qur'an dan Hadith Nusantara (Kuala Lumpur: Akademi Pengajian Islam, 2009), h. 248.

66. Hasil wawancara dengan Prof. Dr. Ismail Luthfi dan para dosen University Fathoni, 20 Oktober 2015.

67. Mushtaffa bin Abdullah dan Abdul Manan Syafi'I, "Khazanah Tafsir di Nusantara: Penelitian terhadap Tokoh dan Karyanya di Malaysia, Brunei Darussalam, Singapura dan Thailand", Jurnal Kontekstualita, Vol. 25 No. 1, Juli 2009, h. 43.

68. Mushtaffa bin Abdullah dan Abdul Manan Syafi'I, "Khazanah Tafsir di Nusantara: Penelitian terhadap Tokoh dan Karyanya di Malaysia, Brunei Darussalam, Singapura dan Thailand”, Jurnal Kontekstualita, Vol. 25 No. 1, Juli 2009, h. 36.

69. Mushtaffa bin Abdullah dan Abdul Manan Syafi'I, "Khazanah Tafsir di Nusantara, h. 36.

70. Mushtaffa bin Abdullah dan Abdul Manan Syafi'I, "Khazanah Tafsir di Nusantara, h. 36.

71. Wawancara dengan Dr. Abdurrahman Haqqi, 21-22 Oktober 2015.

72. Lihat Amin Maulana, "Pengajian Alquran di Nusantara...", h. 37.129

73. Abdurrahman R.A. Haqqi dan Muhammad Nabil Almunawaar, Tafsir Zanjabil: Surah Ali Imran, Tematik, Modern, Ringkas, (Jakarta: Qisthi Press, 2015), cet. 1, h. 205-206.

74. Abdurrahman R.A. Haqqi dan Muhammad Nabil Almunawaar, Tafsir Zanjabil, h. 206.130 